\title{
SURGICAL CONSIDERATIONS ABOUT THE ANTERIOR SYPHON KNEE OF THE INTERNAL CAROTID ARTERY
}

\author{
AN ANATOMICAL STUDY
}

\begin{abstract}
MURILO S. MENESES* **, DANIELLE MOLINARI*, MARCIA FORTES*, PATRICIA RANGEL*, TATIANA NEVES*, ARI PEDROSO**, RICARDO RAMINA **
\end{abstract}

\begin{abstract}
SUMMARY - An anatomical study about the anterior knee of the intracavernous carotid artery is presented. Twenty cavernous sinuses (CS) were dissected in cadavers using microsurgical techniques. A fibrous ring around the internal carotid artery (ICA) at the CS roof was found in all specimens. This fibrous attachment could be dissected from the surrounding dura and a loose connective tissue could be demonstrated around the ICA. This anatomical finding makes possible the microsurgical approach to vascular lesions of this portion of the ICA, without opening the cavemous sinus.
\end{abstract}

KEY WORDS: surgical anatomy, infraclinoidal carotid artery, cavernous sinus, fibrous ring.

Consideraçōes cirúrgicas sobre o joelho anterior do sifão da artéria carótida interna: estudo anatômico

RESUMO - Apresentamos um estudo anatômico sobre o joelho anterior da porçăo intracavemosa da artéria carótida interna (ACI). Foram dissecados vinte seios cavemosos de cadáveres utilizando técnicas microcinúrgicas. Um anel fibroso em volta da ACI na parte superior do seio cavernoso foi encontrado em todos os casos. Esta fixação fíbrosa pode ser dissecada da dura mater e um tecido conectivo frouxo pode ser visualizado em volta da ACI. Este achado anatômico possibilita o acesso microcirúrgico às lesōes vasculares desta porção da ACI, sem abrir o seio cavernoso.

PALAVRAS-CHAVE: anatomia cirúrgica, artéria carótida (porçăo infraclinóidea), seio cavernoso, anel fibroso.

The surgical treatment of the infra or paraclinoidal carotid artery pathologies presents important technical difficulties. The surgical extradural approach through the lateral wall of the cavernous sinus ${ }^{3}$ has some disadvantages compared to the intravascular neuroradiological techniques conceming giant intracavernous aneurysms ${ }^{\prime \prime}$. The opening of the CS may cause bleeding of difficult control, and the course of cranial nerves (III, IV and V1) ${ }^{13}$ in the lateral wall of the CS increases the risk of postoperative neurological deficits.

The approach to the anterior knee of the carotid syphon without opening the venous structures ${ }^{49}$ can be performed through the section of a fibrous ring around the ICA. This ring is located in the transition between the intracavernous and the intradural portion of the ICA. An anatomical study of the infra or paraclinoidal portion of the ICA, with special interest in the surgical approach to the pathologies in this region, is presented.

*Department of Anatomy, Federal University of Parana; ** Department of Neurosurgery, Curitiba Skull Base Foundation, Curitiba, Brazil. Aceite: 9-julho-1994.

Dr. Murilo S. Meneses - Avenida Getúlio Vargas 2159 - 80250-180 Curitiba PR - Brasil. 


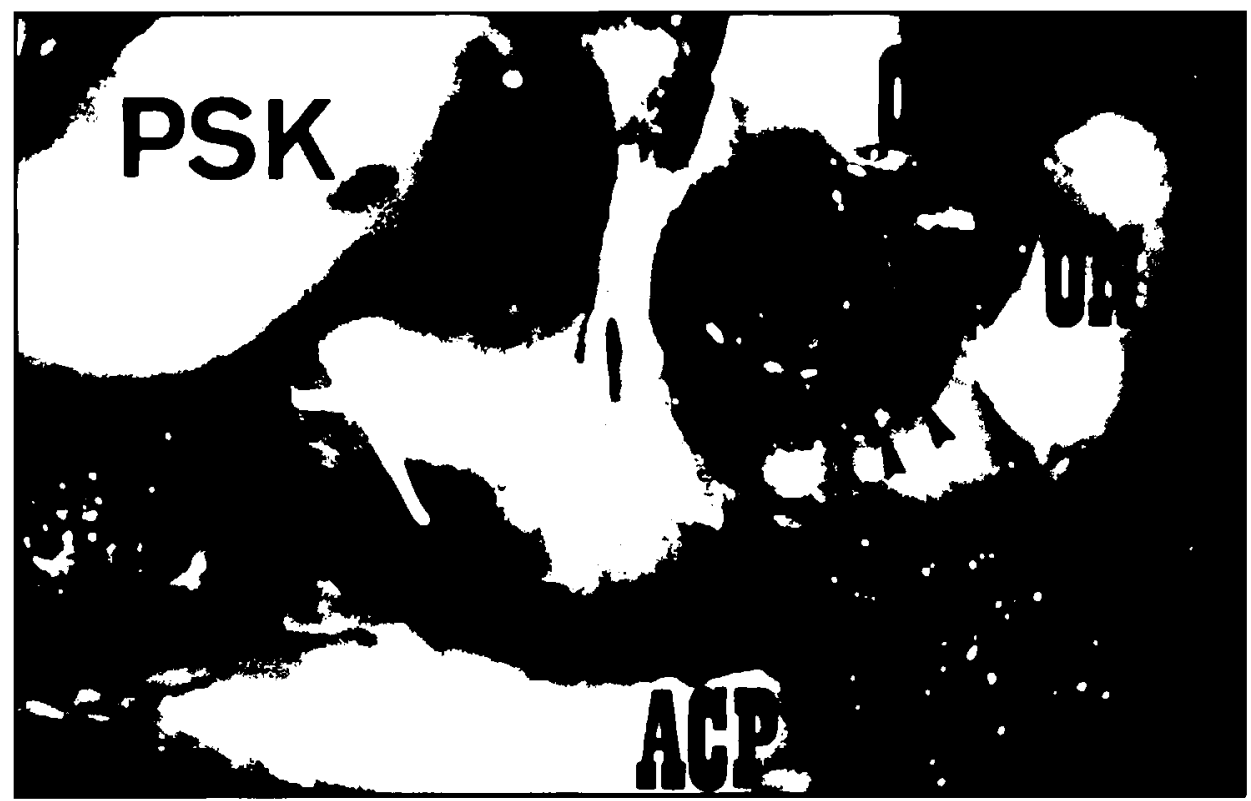

Fig 1. Superior view: the anterior clinoidal process (ACP) is removed, and the optic nerve (ON) is cut to permit the visualization of the ophthalmic artery $(O A)$ and the position of the fibrous ring (small arrows). The posterior syphon knee is also seen.

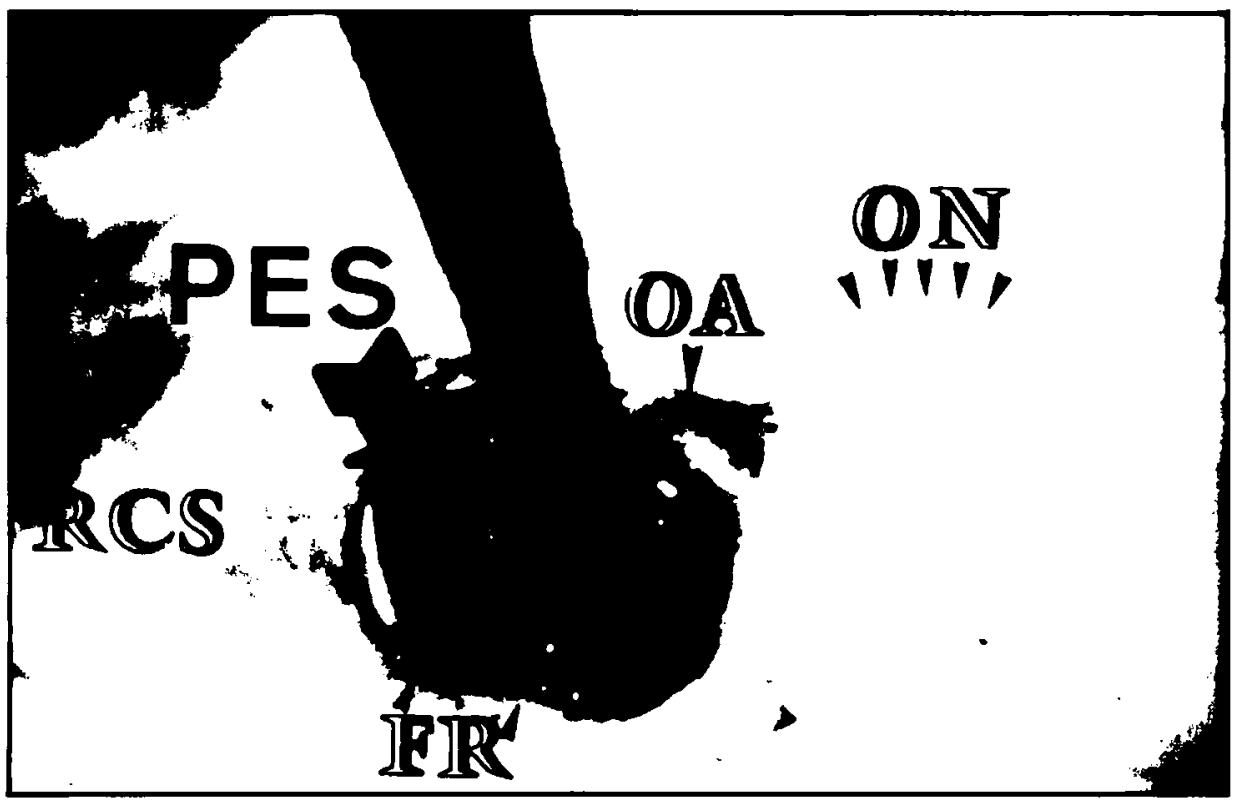

Fig 2. Superior view: the fibrous ring (FR) is cut and the internal carotid artery is retracted. The perivascular extracavernous space (arrow) is shown under the roof of the cavernous sinus (RCS). The ophthalmic artery (OA) and the optic nerve (ON and small arrows) are also seen. 


\section{MATERIAL, METHODS AND RESULTS}

Twenty anatomical specimens were studied with microsurgical techniques. The arteries were filled with latex or red colored glue in 18 cases and the cavemous sinus was filled with blue latex in 4 cases. The dissections were realized with an operative microscope, studying the ICA, ophthalmic artery and the optic, oculomotor, trochlear, ophthaimic and abducent nerves. The cavernous sinus was examined through the opening of its lateral wall. Special attention was paid to the dimensions of the space between the cavernous sinus and the ICA under the fibrous ring. Laterally to the ICA, at the transition between intradural and intracavernous portion, the anterior clinoidal process (ACP) limits the microsurgical exposition. This extension of the lesser sphenoid wing can be removed by drilling after section and dissection of the dura-mater. The ACP may present anatomical variations in some cases, involving the ICA.

After perforating the dura-mater, the ICA has adhesions to some structures, like the diaphragma sellae and the ACP. A strong connective tissue creates a fibrous ring at the roof of the CS (Fig 1).

Besides removal of the ACP, it is also necessary to open the optic canal to allow mobilization of the optic nerve. With sharp dissection the fibrous ring is opened. A perivascular extracavernous space filled with loose connective tissue is exposed (Fig 2). The approach to the ICA pathologies, as in paraclinoidal aneurysms, is possible through this space. The average measures of this space are: lateral $5.9 \mathrm{~mm}$, anterior $4.4 \mathrm{~mm}$, medial 5.3 $\mathrm{mm}$ and posterior $5.3 \mathrm{~mm}$. In its medial part, the connective tissue is less firm and permits an easier dissection.

\section{COMMENTS}

The technical difficulties of approaching the anterior knee of the ICA presents a particular neurosurgical interest. In this region aneurysms and tumors ${ }^{1,12}$ are in close relationship with important neuro-vascular structures. Aneurysms located at this portion of the ICA are called carotid ophthalmic, infra or paraclinoidal according to their position $5,6-1,11$.

The surgical approach used is pterional ipsilateral to the paraclinoidal ICA region in lateral or anterior located aneurysms.

The ACP is removed intradurally and the optic canal is opened with diamond burrs. Extensive bone removal of the skull base is performed in special cases ${ }^{2}$. The optic nerve can be gently mobilized to permit a better visualization of the paraclinoidal ICA. In some cases, as posterior and medial located aneurysms, a contralateral approach may be used. In this cases it is also necessary to remove the tuberculum sellae and the medial wall of the optic canal.

The ICA presents a fibrous ring in its transition between the cavernous sinus and the intradural portion, when perforating the dura-mater. This ring can be sectioned, giving a space around the ICA, without opening the CS avoiding venous bleeding. The connective tissue in this space is loose and permits an easy dissection avoiding injury to the cranial nerves, allowing to approach the anterior knee of the carotid syphon. This approach gives more than $5 \mathrm{~mm}$ exposure around the ICA, under the fibrous ring, permitting to clip the neck of an aneurysm.

\section{REFEREKCES}

1. Al-Mefty O, Khalil N, Elwany MN. Smith RR. Shunt for bypass graft of the cavernous carotid artery: an anatomical and technical study. Neurosurgery 1990, 27: 721-728.

2. Diaz FG, Ohaegbulam S, Dujovny M, Ausman JI. Surgical altematives in the treatment of cavernous sinus aneurysms. J Neurosurg 1989, 71: 846-856.

3. Dolenc V. Direct microsurgical repair of intracavemous vascular lesions. J Neurosurg 1983, 58: 824-831.

4. Inove T, Rhoton AL Jr, Theele D, Barry ME. Surgical approaches to the cavernous sinus: a microsurgical study. Neurosurgery 1990, 26: $903-932$.

5. Knosp E, Muller G, Pemeczky A. The paraclinoid carotid artery: anatomical aspects of a microsurgical approach. Neurosurgery 1988, 22: 896-901.

6. Kobayashi S, Kyoshima K, Gibo H, Hegde SA, Takemae T, Sugita K. Carotid cave aneurysms of the internal carotid artery. J Neurosurg 1989, 70: 216-221.

7. Linskey ME, Sekhar LN, Hirsch WL Jr, Yonas H, Horton JA. Aneurysms of the intracavernous carotid artery: natural history and indications for treatment. Neurosurgery 1990, 26: 933-938. 
8. Ohmoto T, Nagao S, Mino S, Ito T, Honma Y, Fujiwara T. Exposure of the intracavernous carotid artery in aneurysm surgery. Neurosurgery 1991, 28: 317-324.

9. Perneczky A, Knosp E, Matula Ch. Cavemous sinus surgery: approach through the lateral wall. Acta Neurochir (Wien) 1988, 92: 76-82.

10. Perneczky A, Knosp E, Vorkapic P, Czech T. Direct surgical approach to infraclinoidal aneurysms. Acta Neurochir (Wien) 1985, 76: 36-44.

11. Perneczky A, Knosp E, Zohdi A. Surgery of vascular lesions in the cavernous sinus. In: Samii M (ed) Surgery of the sellar region and paranasal sinuses. Berlim: Springer-Verlag, 1991, p 494-501.

12. Sekhar LN, Moller AR. Operative management of tumors involving the cavernous sinus. J Neurosurg 1986 , 64: 879-889.

13. Umansky F, Nathan $H$. The lateral wall of the cavernous sinus with special reference to the nerves related to it. J Neurosurg 1982, 56: 228-234. 